\title{
Germinated Brown Rice Alters A $\beta(1-42)$ Aggregation and Modulates Alzheimer's Disease-Related Genes in Differentiated Human SH-SY5Y Cells
}

\author{
Nur Hanisah Azmi, ${ }^{1}$ Maznah Ismail, ${ }^{1,2}$ Norsharina Ismail, ${ }^{1}$ Mustapha Umar Imam, ${ }^{1}$ \\ Noorjahan Banu Mohammed Alitheen, ${ }^{3}$ and Maizaton Atmadini Abdullah ${ }^{4}$ \\ ${ }^{1}$ Nutricosmeceuticals and Nutrigenomics Programme, Laboratory of Molecular Biomedicine, Institute of Bioscience, \\ Universiti Putra Malaysia, 43400 Serdang, Selangor, Malaysia \\ ${ }^{2}$ Department of Nutrition and Dietetics, Faculty of Medicine and Health Sciences, Universiti Putra Malaysia, 43400 Serdang, \\ Selangor, Malaysia \\ ${ }^{3}$ Department of Cell and Molecular Biology, Faculty of Biotechnology and Biomolecular Sciences, Universiti Putra Malaysia, \\ 43400 Serdang, Selangor, Malaysia \\ ${ }^{4}$ Department of Pathology, Faculty of Medicine and Health Sciences, Universiti Putra Malaysia, 43400 Serdang, Selangor, Malaysia
}

Correspondence should be addressed to Maznah Ismail; maznahis@upm.edu.my

Received 2 September 2015; Revised 25 November 2015; Accepted 26 November 2015

Academic Editor: Gerald Munch

Copyright (c) 2015 Nur Hanisah Azmi et al. This is an open access article distributed under the Creative Commons Attribution License, which permits unrestricted use, distribution, and reproduction in any medium, provided the original work is properly cited.

\begin{abstract}
The pathogenesis of Alzheimer's disease involves complex etiological factors, of which the deposition of beta-amyloid (A $\beta$ ) protein and oxidative stress have been strongly implicated. We explored the effects of $\mathrm{H}_{2} \mathrm{O}_{2}$, which is a precursor for highly reactive hydroxyl radicals, on neurotoxicity and genes related to $\mathrm{AD}$ on neuronal cells. Candidate bioactive compounds responsible for the effects were quantified using HPLC-DAD. Additionally, the effects of germinated brown rice (GBR) on the morphology of A $\beta(1-42)$ were assessed by Transmission Electron Microscopy and its regulatory effects on gene expressions were explored. The results showed that GBR extract had several phenolic compounds and $\gamma$-oryzanol and altered the structure of A $\beta(1-42)$ suggesting an antiamyloidogenic effect. GBR was also able to attenuate the oxidative effects of $\mathrm{H}_{2} \mathrm{O}_{2}$ as implied by reduced LDH release and intracellular ROS generation. Furthermore, gene expression analyses showed that the neuroprotective effects of GBR were partly mediated through transcriptional regulation of multiple genes including Presenilins, APP, BACE1, BACE2, ADAM10, Neprilysin, and LRP1. Our findings showed that GBR exhibited neuroprotective properties via transcriptional regulation of APP metabolism with potential impact on $\mathrm{A} \beta$ aggregation. These findings can have important implications for the management of neurodegenerative diseases like $\mathrm{AD}$ and are worth exploring further.
\end{abstract}

\section{Background}

Alzheimer's disease (AD) is a progressive disorder of the central nervous system, with huge economic burden to individuals and their societies [1]. AD progression is accompanied by gradual loss of neurons responsible for learning and memory. Beta-amyloid $(\mathrm{A} \beta)$ plaques are often found deposited in the brain of AD patients and may be responsible for the loss of synaptic transmission and neuronal death that are characteristic of $\mathrm{AD}$ [2]. Even though $\mathrm{AD}$ has a complex pathogenesis and its etiology is not precisely understood, major findings have suggested that dysregulation of amyloid precursor protein (APP) metabolism plays a major role in the generation of neurotoxic $\mathrm{A} \beta$ [2]. Accordingly, differential regulation of APP metabolic processing involving $\alpha$-, $\beta$-, or $\gamma$-secretases will result in either amyloidogenic or nonamyloidogenic products with huge implications for disease outcomes [3].

In normal physiologic condition, APP is cleaved by $\alpha$ secretase to produce the nonamyloidogenic soluble neurotrophic fragment $(\mathrm{sAPP} \alpha)$, thereby precluding the formation of the toxic $\mathrm{A} \beta$ [4]. On the other hand, cleavage of APP by 
$\beta$-secretase and $\gamma$-secretase follows the amyloidogenic pathway, thus releasing $A \beta$ peptides into the extracellular matrix [5]. The $\beta$-secretase components include $\mathrm{A} \beta$ cleaving enzymes 1 and 2 (BACE1 and BACE2, resp.) while $\gamma$-secretase is formed by Presenilin, nicastrin, Aph-1, and Pen-2 [5-7]. Despite clear evidence that inherited mutations of APP and Presenilin genes are causal factors for early onset familial AD $[8,9]$, the exact mechanism underlying overproduction of $A \beta$ in late onset sporadic $\mathrm{AD}$ is not known, even though sporadic $\mathrm{AD}$ accounts for the majority of $\mathrm{AD}$ cases.

As can be recalled, oxidative stress in the brain often results from inability of endogenous antioxidant defense to counter the reactive oxygen species (ROS) produced by the brain cells. Experimental models had demonstrated the JNK-dependent upregulation of BACE1 and $\gamma$-secretase activity as a result of oxidative stress [10] in neuroblastoma cells. Similarly, PC12 cells induced by hydrogen peroxide $\left(\mathrm{H}_{2} \mathrm{O}_{2}\right)$ significantly increased BACE1-promoter activity and augmented $A \beta$ production from APP carrying the human Swedish mutation [11]. Furthermore, disruption of APP metabolism has been demonstrated in oxidative stress $[10,11]$, while increased levels of BACE1 have been reported in the brain region of sporadic $\mathrm{AD}$ patients [12]. These findings are further supported by the links between oxidative stress, altered mitochondrial function, and dysregulation of calcium hemostasis that precede $\mathrm{A} \beta$ plaques development with $\mathrm{AD}$ neuropathology $[13,14]$.

It has been proposed that antioxidants have huge potentials in preventing and/or delaying the development and progression of neurodegenerative diseases including $\mathrm{AD}$ [15]. This has driven the search for potent antioxidants with neuroprotective potentials. Germinated brown rice (GBR) has been reported to possess important biological activities including antioxidative and neuroprotective properties [16, 17]. Additionally, it was reported to protect neuronal cells from oxidative stress-induced cytotoxicity, alleviate depressionlike behaviors as well as enhance learning ability, and improve memory impairment resulting from $\mathrm{A} \beta$ administration [1821]. These properties of GBR are thought to be mediated by its bioactive-rich constituents [22]. At present, there is limited knowledge on the effects of oxidative stress on normally expressed APP. Nonetheless, it is suggested to represent a near-physiological model of neuronal $\mathrm{A} \beta$ generation [10]. Since $\mathrm{H}_{2} \mathrm{O}_{2}$ is the main source of the highly reactive hydroxyl radical in the brain, in the present work we studied its effects on the levels of and processing of human APP by $\alpha-, \beta-$, and $\gamma$-secretase and the role of the low density lipoprotein receptor-related protein (LRP) and Neprilysin, as well as the potential of GBR to attenuate such processes. This study is also the first to explore the modulation of APP metabolism in differentiated human neuroblastoma cells by GBR as well as its effect on the aggregation of $A \beta$ in vitro.

\section{Materials and Methods}

2.1. Materials and Chemicals. Brown rice (BR) of Malaysian mixed varieties (MR219 and MR220) was procured from Padiberas Nasional (BERNAS) factory, Seri Tiram Jaya, Selangor. Food grade $\mathrm{H}_{2} \mathrm{O}_{2}$ and sodium hypochlorite
( $\mathrm{NaOCl})$ were purchased from Bendosen Laboratory Chemicals (Selangor, Malaysia) and from Dexchem Industries Sdn. Bhd. (Penang, Malaysia), respectively. Human SH-SY5Y neuroblastoma cell line was purchased from the American Type Culture Collection (ATCC), USA. Dulbecco's Modified Eagle's Medium/Nutrient F-12 mixture, fetal bovine serum, gentamicin, phosphate-buffered saline (PBS), human A $\beta(1-42)$, 2,7-dichlorodihydrofluorescein diacetate (DCFHDA), and trypsin were purchased from Sigma-Aldrich (St. Louis, MO, USA). Analytical grade $\mathrm{H}_{2} \mathrm{O}_{2}$ was purchased from Merck (Darmstadt, Germany), while CytoTox96 NonRadioactive Cytotoxicity Assay was purchased from Promega (Southampton, UK). The GenomeLab GeXP Start Kit was purchased from Beckman Coulter, Inc. (Miami, FL, USA), and the Total RNA Isolation Kit was purchased from RBC Bioscience Corp. (Taipei, Taiwan). Magnesium chloride $\left(\mathrm{MgCl}_{2}\right)$, DNA Taq polymerase, HPLC grade water, acetic acid, acetonitrile, methanol, and isopropanol were purchased from Thermo Fisher Scientific (Pittsburgh, PA, USA).

2.2. Germination of Brown Rice and Extraction. BR was germinated as reported in an earlier publication [16]. Briefly, $\mathrm{BR}$ was sterilized in $0.1 \% \mathrm{NaOCl}(1: 5, \mathrm{w} / \mathrm{v})$ for $30 \mathrm{~min}$ and incubated in $0.5 \% \mathrm{H}_{2} \mathrm{O}_{2}(1: 5, \mathrm{w} / \mathrm{v})$ for $6 \mathrm{~h}$. The solvents were discarded and the BR was further incubated at $37^{\circ} \mathrm{C}$ for another $18 \mathrm{~h}$ in anoxic condition. Germination was evidenced by the growth of sprouts. After drying at $50^{\circ} \mathrm{C}$, the final moisture content was between 8 and $11 \%$. Dried GBR was ground using a grinder and extracted using ethyl acetate as previously described [23]. Briefly, GBR powder was dissolved in ethyl acetate $(1: 4 \mathrm{w} / \mathrm{v})$. The mixtures were sonicated for $1 \mathrm{~h}$. The extract was filtered through Whatman filter paper number 1 and the entire extraction process was repeated twice on the residue obtained from the filtration process. The filtrates were pooled and solvent was removed from the filtrates under reduced pressure (Rotavapor R210, Buchi, Postfach, Flawil, Switzerland). Finally, the extracts were cooled in a desiccator and kept at $-80^{\circ} \mathrm{C}$ until further analyses.

\subsection{High Performance Liquid Chromatography (HPLC-DAD).} HPLC analysis for phenolic compounds was performed using Agilent G1310A pumps (Agilent, Santa Clara, CA, USA) with a diode array detector set at wavelengths of $280 \mathrm{~nm}$ and $320 \mathrm{~nm}$. Chromatographic separations were performed on a LUNA C-18 column $(5 \mathrm{~mm}, 250 \times 4.6 \mathrm{~mm})$ (Phenomenex, Torrance, CA, USA). The solvent composition and gradient elution conditions used were the same as those described previously [17]. The mobile phase was composed of solvent (A) water-acetic acid (94:6, v/v, pH 2.27) and solvent (B) acetonitrile. The solvent gradient was $0-15 \%$ B for $40 \mathrm{~min}$, $15-45 \% \mathrm{~B}$ for $40 \mathrm{~min}$, and $45-100 \% \mathrm{~B}$ for $10 \mathrm{~min}$. A flow rate of $0.5 \mathrm{~mL} / \mathrm{min}$ was used and $20 \mu \mathrm{L}$ of sample was injected. Samples and mobile phases were filtered through a $0.22 \mu \mathrm{m}$ Millipore filter, type GV (Millipore, Bedford, MA, USA), prior to HPLC injection. Samples were analyzed in triplicate. Determination and quantification of phenolic compounds were done by comparing their retention times and UV-Vis spectral data to known, previously injected standards. 
Oryzanol content was analyzed according to Azlan et al. [24] using reverse-phase HPLC. The HPLC system consisted of Hewlett-Packard (Germany) Model G1311A High Performance Liquid Chromatography connected to ALS Autoinjector Series 1100 (Hewlett-Packard, Germany). The mobile phase consisted of acetonitrile/methanol/isopropanol ( $50: 45: 5$ by volume). Oryzanol components were detected at $325 \mathrm{~nm}$ with a Hewlett-Packard Model 1100 Series Photodiode Array Detector. Oryzanols were separated using a 250 $\times 4 \mathrm{~mm}$ id Hewlett-Packard column packed with $5 \mathrm{~mm}$ ODSC18 Hypersil silica.

2.4. Transmission Electron Microscopy (TEM). Twenty microliters $(20 \mu \mathrm{L})$ of $20 \mu \mathrm{M} \mathrm{A} \beta(1-42)$ was incubated with or without the presence of $1 \mathrm{ppm}$ and $10 \mathrm{ppm}$ GBR extract for 48 hours at $37^{\circ} \mathrm{C}$. The concentrations of GBR extract ( 1 and $10 \mathrm{ppm}$ ) were chosen based on previous determination [23]. The samples were prepared on continuous carbon support films, followed by glow discharging and negative staining of $2 \%$ aqueous uranyl acetate ( $\mathrm{pH} 4.5)$ by the single droplet procedure. The $\mathrm{A} \beta(1-42)$ in the presence and absence of GBR extract was adsorbed onto the carbon film for $5 \mathrm{~min}$, dried on a filter paper, and incubated with uranyl acetate solution individually and was viewed under TEM Philips HMG 400 at $10,000 x$ and 20,000x magnifications. A representative assessment of $\mathrm{A} \beta$ fibril formation was made at several positions across each EM grid, to avoid any biased or subjective data selection.

2.5. Cell Culture. The human neuroblastoma SH-SY5Y cells were grown in complete culture medium containing mixture of Minimum Essential Eagle's Medium and Ham's Nutrient F-12 (1:1), which was supplemented with $10 \%$ fetal bovine serum, $1 \%$ MEM nonessential amino acids, and $50 \mu \mathrm{g} / \mathrm{mL}$ gentamicin. Cells were maintained at $37^{\circ} \mathrm{C}$ under $5 \% \mathrm{CO}_{2}$ and $95 \%$ air.

2.6. MTT Assay. For determination of neuroprotective effects of GBR extract on $\mathrm{A} \beta(1-42)$ toxicity, MTT analysis was carried out. SH-SY5Y cells were seeded at a density of $2 \times$ $10^{5}$ cells $/ \mathrm{mL}$ in a 96-well plate. Two days after seeding, cells were differentiated with $10 \mu \mathrm{M}$ retinoic acid for 6 days prior to treatment. Human $A \beta(1-42)$ was diluted to $200 \mu \mathrm{M}$ and incubated at $37^{\circ} \mathrm{C}$ for $48 \mathrm{~h}$ to produce aggregated $\mathrm{A} \beta$ in order to cause toxicity to the cells. Cells were pretreated with GBR extract at $1 \mathrm{ppm}$ and $10 \mathrm{ppm}$ for $24 \mathrm{~h}$ before being exposed to aggregated $\mathrm{A} \beta(1-42)$ at final concentration of $20 \mu \mathrm{M}$ for another $24 \mathrm{~h}$ prior to MTT analysis.

2.7. Lactate Dehydrogenase (LDH) Release Assay. LDH release was determined using CytoTox96 Non-Radioactive Cytotoxicity Assay (Promega, Southampton, UK). In this colorimetric assay, LDH converts lactate and nicotinamide adenine dinucleotide (NAD+) to pyruvate and NADH, respectively. This initial reaction is coupled to a second reaction where diaphorase converts iodonitrotetrazolium salt and NADH to a red colored formazan compound and NAD+, respectively. Cells were seeded at a density of
$2 \times 10^{5}$ cells $/ \mathrm{mL}$ in a 96-well plate. After 2 days of seeding, cells were differentiated with $10 \mu \mathrm{M}$ retinoic acid for 6 days prior to treatment. Cells were pretreated with GBR extract $(1 \mathrm{ppm}$ and $10 \mathrm{ppm})$ for $24 \mathrm{~h}$ prior to treatment with $250 \mu \mathrm{M}$ $\mathrm{H}_{2} \mathrm{O}_{2}$ for another $2 \mathrm{~h}$ [23]. After cells were exposed to $\mathrm{H}_{2} \mathrm{O}_{2}$ with or without pretreatment with GBR, $50 \mu \mathrm{L}$ of the cell culture medium was transferred from each well of the assay plate to the corresponding well of flat bottom 96-well assay plate. Maximum LDH release was achieved by adding Lysis Buffer to the corresponding wells and $50 \mu \mathrm{L}$ of the medium was used. Substrate mix was reconstituted using Assay Buffer, from which $50 \mu \mathrm{L}$ was added to each well of the plate. The plate was covered and incubated at room temperature and protected from light for 30 minutes, after which $50 \mu \mathrm{L}$ of stop solution was added to each well of plate. Absorbance was read at $490 \mathrm{~nm}$ using on BioTek Synergy H1 Hybrid Reader (BioTek Instruments Inc., Winooski, VT, USA). The results were calculated using the formula

$$
\begin{aligned}
\% \mathrm{LDH} \text { release }= & \left(\frac{\mathrm{LDH} \text { release in the medium }}{\max . \mathrm{LDH} \text { release }}\right) \\
& * 100 .
\end{aligned}
$$

2.8. DCFH-DA Intracellular ROS Production. Free radical production was measured by incubating the cells with the fluorescent probe $2^{\prime}, 7^{\prime}$-dichlorodihydrofluorescein diacetate (DCFH-DA) according to Rosenkranz et al. [25] with modifications. DCFH-DA freely crosses the cell membranes and it is hydrolyzed by cellular esterases to $2 \mathrm{~V}, 7 \mathrm{~V}$ dichlorodihydrofluorescein, a nonfluorescent molecule that can be oxidized to the fluorescent $2 \mathrm{~V}, 7 \mathrm{~V}$-dichlorofluorescein (DCF) in the presence of peroxides. Cells were seeded at a density of $2 \times 10^{5}$ cells $/ \mathrm{mL}$ in a black 96-well plate and differentiated for 6 days. Prior to treatment with GBR extract, media were discarded and cells were incubated with $100 \mu \mathrm{L}$ of $10 \mu \mathrm{M}$ of DCFH-DA for 30 minutes. DCFH-DA was discarded, and cells were washed twice with PBS and pretreated with GBR extract for $24 \mathrm{~h}$. Then, $250 \mu \mathrm{M} \mathrm{H}_{2} \mathrm{O}_{2}$ was added to respective wells and accumulation of DCF in the cells was measured as an increase in fluorescence ( $480 \mathrm{~nm}$ excitation, $510 \mathrm{~nm}$ emission) for another $2 \mathrm{~h}$ on BioTek Synergy H1 Hybrid Reader (BioTek Instruments Inc., Winooski, VT, USA).

\subsection{Multiplex Gene Expression Analysis}

2.9.1. Primer Design. Primers were designed on the GenomeLab eXpress Profiler software using Homo sapiens sequence adopted from the National Center for Biotechnology Information GenBank Database. The genes of interest, housekeeping genes, and internal control are shown in Table 1. The forward and reverse primers had universal tag sequences in addition to nucleotides that were complementary to the target genes. Primers were supplied by First Base Ltd. (Selangor, Malaysia) and diluted in 1x TE Buffer to a concentration of $500 \mathrm{nM}$ for reverse primers and $200 \mathrm{nM}$ for forward primers.

2.9.2. Extraction of RNA. Cells were seeded at a density of $2 \times 10^{5}$ cells $/ \mathrm{mL}$ in 6 -well plate. After 2 days of seeding, cells 


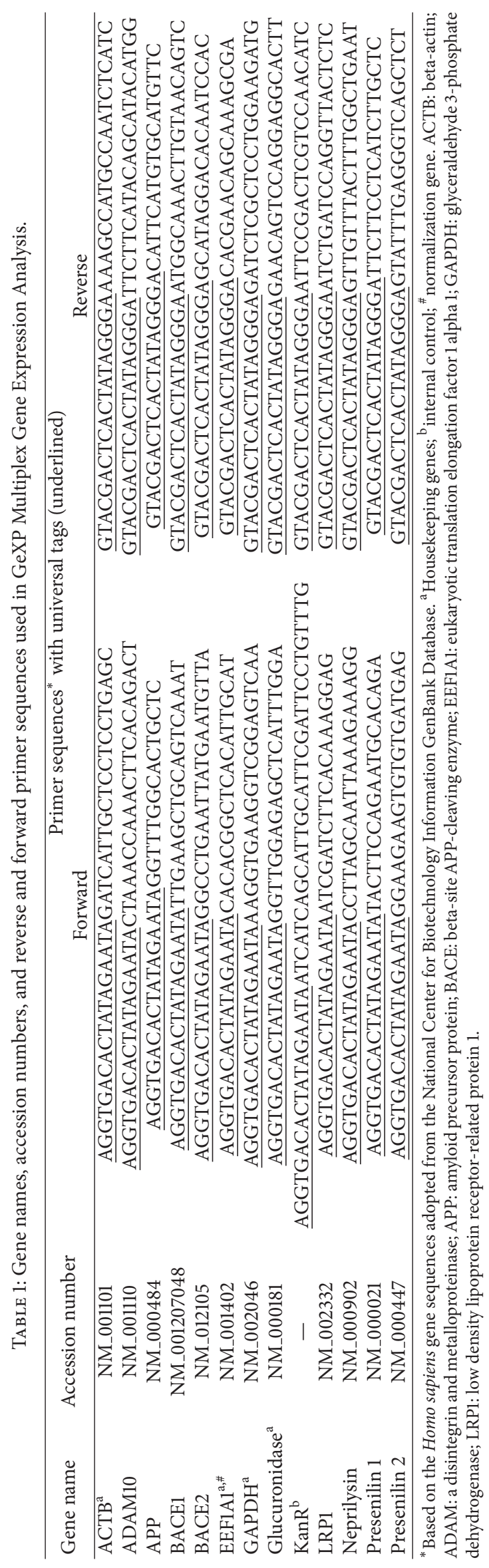


were differentiated with $10 \mu \mathrm{M}$ retinoic acid for 6 days. Cells were pretreated with GBR extract for $24 \mathrm{~h}$ prior to treatment with $250 \mu \mathrm{M} \mathrm{H}_{2} \mathrm{O}_{2}$ for another $2 \mathrm{~h}$. Treated SH-SY5Y cells were washed with phosphate-buffered saline (PBS), and RNA was isolated using Total RNA Isolation Kit (RBC Bioscience Corp., Taiwan) according to manufacturer's instructions. RNA concentration was determined using NanoDrop spectrophotometer (Thermo Scientific NanoDrop, NanoDrop Technologies, Wilmington, DE, USA). The ratios of A260/230 and A260/280 were used to indicate the purity of extracted total RNA.

2.9.3. Reverse Transcription and Polymerase Chain Reaction (PCR). Reverse transcription (RT) and multiplex PCR of RNA samples $(50 \mathrm{ng} / \mu \mathrm{L})$ were carried out in XP Thermal Cycler (BIOER Technology, Hangzhou, China) according to the GenomeLab GeXP Start Kit protocol (Beckman Coulter, Inc., Miami, FL, USA). Briefly, RT reaction mixture was prepared using RNA sample ( $1 \mu \mathrm{L}$ each), $4 \mu \mathrm{L}$ of $5 x$ RT Buffer, $2 \mu \mathrm{L}$ of RT reverse primers, $1 \mu \mathrm{L}$ of KanR, $1 \mu \mathrm{L}$ of reverse transcriptase, and $11 \mu \mathrm{L}$ of DNAse/RNase-free water. cDNA was synthesized according to the reaction protocol: $48^{\circ} \mathrm{C}$ for $1 \mathrm{~min}, 42^{\circ} \mathrm{C}$ for $60 \mathrm{~min}, 95^{\circ} \mathrm{C}$ for $5 \mathrm{~min}$, and $4^{\circ} \mathrm{C}$ hold. Then, $9.3 \mu \mathrm{L}$ of each RT product was mixed with $10.7 \mu \mathrm{L}$ of PCR reaction mixture consisting of $5 \mathrm{x}$ PCR Buffer, $25 \mathrm{mM}$ $\mathrm{MgCl}_{2}$, PCR forward primer plex, and Thermo-Start DNA polymerase. Amplification conditions were $95^{\circ} \mathrm{C}$ for $10 \mathrm{~min}$, followed by $34 \mathrm{cycles}$ of $94^{\circ} \mathrm{C}$ for $30 \mathrm{sec}, 55^{\circ} \mathrm{C}$ for $30 \mathrm{sec}, 70^{\circ} \mathrm{C}$ for $1 \mathrm{~min}$, and $4^{\circ} \mathrm{C}$ hold.

2.9.4. GeXP Data Analysis. PCR products ( $1 \mu \mathrm{L}$ each) from the above reactions were mixed with $38.5 \mu \mathrm{L}$ of sample loading solution and $0.5 \mu \mathrm{L}$ of DNA size standard 400 (Beckman Coulter, Inc., Miami, FL, USA) in a 96-well sample loading plate and analyzed on the GeXP machine (Beckman Coulter, Inc., Miami, FL, USA). The results from the machine were analyzed using the Fragment Analysis module of the GeXP system software and then imported onto the analysis module of eXpress Profiler software. Normalization was performed with EEF1A1 according to manufacturer's instructions.

2.10. Statistical Analysis. Data were analyzed by using SPSS (Statistical Program for the Social Sciences version 20, SPSS Inc., USA). All experiments were carried out in triplicate. The results were expressed as mean $\pm \mathrm{SD}$. Analyses of variances (ANOVA) were carried out to evaluate the significant difference, and Tukey tests were used to determine the significance of the difference. Linear correlation was determined using Pearson correlation, and $p<0.05$ was considered significant.

\section{Results and Discussion}

3.1. HPLC Determination of GBR Bioactive Compounds. The germination process of $\mathrm{BR}$ is known to affect its composition and functional properties [26]. The improved concentration of several bioactive compounds present in GBR is suggested to be responsible for its health beneficial effects. In the present study, the bioactive compounds shown in Table 2
TABLE 2: Bioactive compounds in ethyl acetate extract of germinated brown rice as determined by HPLC-DAD.

\begin{tabular}{lc}
\hline Compounds & $\begin{array}{c}\text { Concentration } \\
\text { (mg/g extract) }\end{array}$ \\
\hline Guaiacol & $0.023 \pm 0.04$ \\
2MHQ & $0.947 \pm 0.03$ \\
Rosmarinic acid & $0.046 \pm 0.04$ \\
Cinnamic acid & $0.654 \pm 0.02$ \\
Cycloartenyl ferulate & $2.219 \pm 0.32$ \\
24-Methylene cycloartanyl ferulate & $5.35 \pm 0.67$ \\
Campesteryl ferulate & $2.74 \pm 0.74$ \\
Mixtures of $\beta$-sitosteryl ferulate and & $6.30 \pm 0.10$ \\
\hline
\end{tabular}

Values represent mean $\pm \mathrm{SD}(n=3)$.

may have contributed to the bioactivity of the extract. The ethyl acetate extract of GBR was found to contain guaiacol, 2MHQ, rosmarinic acid, cinnamic acid, and $\gamma$-oryzanols (cycloartenyl ferulate, 24-methylene cycloartanyl ferulate, campesteryl ferulate, and mixtures of $\beta$-sitosteryl ferulate and cycloartanyl ferulate).

Although other bioactive compounds have been reported in GBR [26], the choice of ethyl acetate in this study may have precluded their extraction. However, the presence of multiple bioactive compounds in the ethyl acetate extract may contribute to synergistic improvements in bioactivity. Moreover, the bioactivity of GBR is reported to be due to the presence of multiple bioactive compounds through the process of food synergy, and as the data here demonstrates, any bioactivity observed in the present study would be attributed to the presence of multiple compounds, as we have demonstrated severally [27]. As can be recalled, oxidative stress is strongly implicated in neuronal cell death in $\mathrm{AD}$ [14]. Furthermore, the bioactive compounds in the ethyl acetate extract of GBR are mostly phenolics, which have been shown to have potent antioxidant effects, and as such can counter the effects of oxidative stress [28].

3.2. Antiamyloidogenic Properties of GBR. Due to the limited capability of neuron cells to regenerate, it is vital to prevent cell death through regulation of oxidative stress and $\beta$ amyloid production, formation, fibrillogenesis, and deposition in order to prevent their damaging effects on brain cells. As such, compounds or drugs that are able to regulate these processes have huge potentials in the management of $\mathrm{AD}$. Accordingly, anti-inflammatory drugs [29] and antioxidative compounds [30] have been shown to prevent and slow down the onset of $\mathrm{AD}$, through possessing antiamyloidogenic properties. Additionally, recent studies have shown that epigallocatechin gallate (EGCG) [31] and cannabinoids [32] can reduce the formation of $\mathrm{A} \beta$ fibrils and aggregates formation, while a hybrid of the AD drug tacrine, tacrine-6-ferulic acid dimer, was reported to alter the conformation of $\mathrm{A} \beta$ and block $\mathrm{A} \beta$-induced cell death as its possible neuroprotective action [33]. In this study, ethyl acetate extract of GBR also altered $\mathrm{A} \beta$ formation (Figure 1). In the absence of GBR 


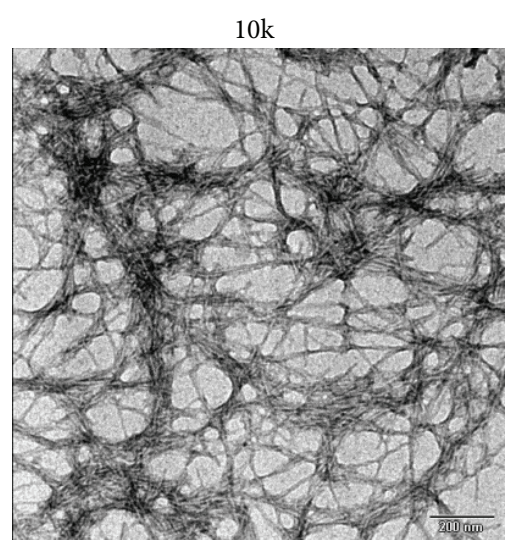

$20 \mathrm{k}$

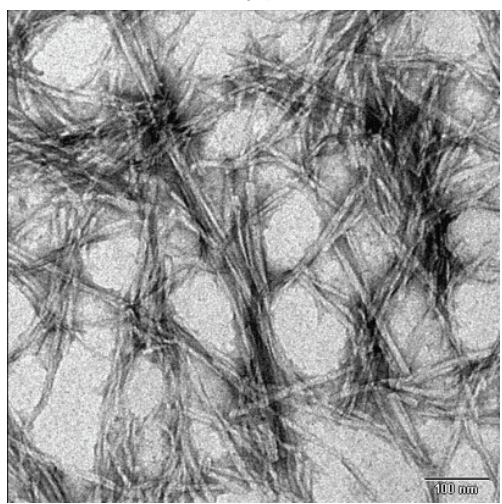

(a) $\mathrm{A} \beta(1-42)$

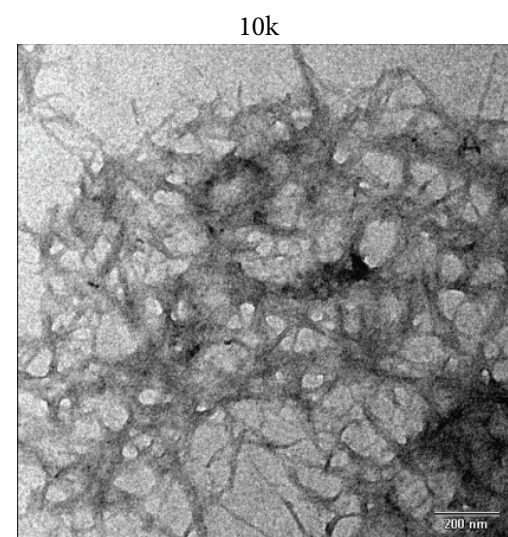

$20 \mathrm{k}$

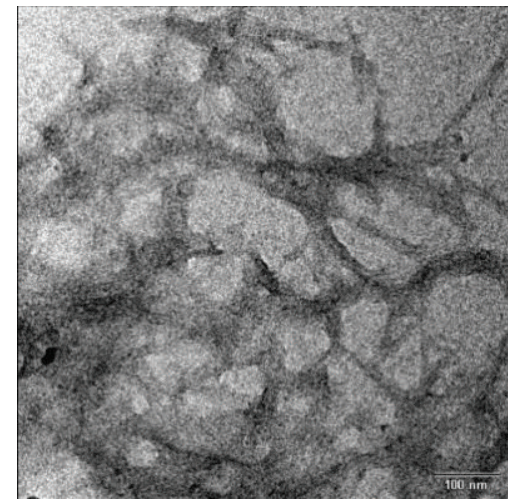

(b) $\mathrm{A} \beta(1-42)+\mathrm{GBR} 1 \mathrm{ppm}$
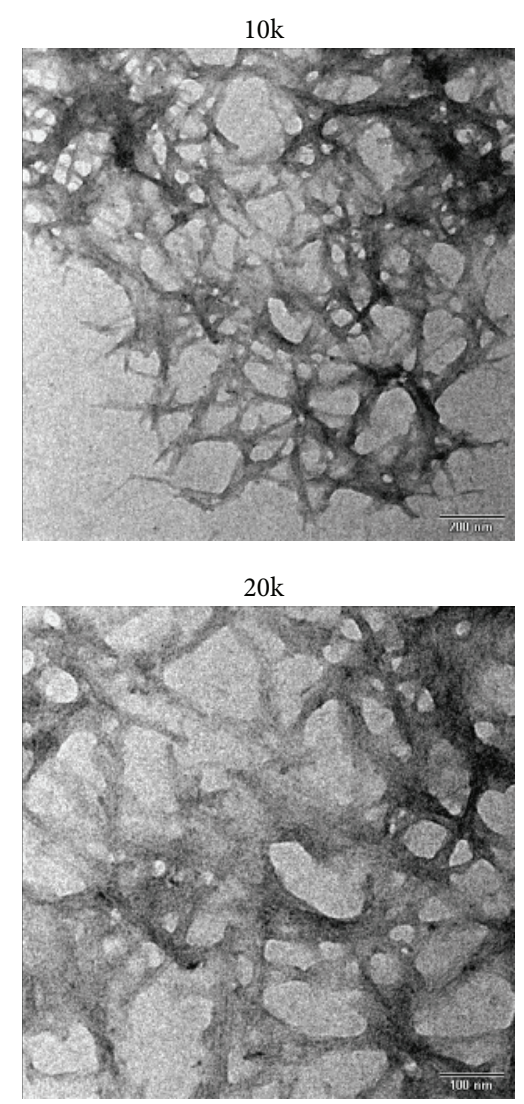

(c) $\mathrm{A} \beta(1-42)+\mathrm{GBR} 10 \mathrm{ppm}$

FIgure 1: Antiamyloidogenic properties of GBR. (a) $20 \mu \mathrm{M} \mathrm{A} \beta(1-42)$ incubated for $48 \mathrm{~h}$ at $37^{\circ} \mathrm{C}$ under near-physiological conditions assembled into negatively stained amyloid fibrils. (b and c) $20 \mu \mathrm{M} \mathrm{A} \beta(1-42)$ in the presence of $1 \mathrm{ppm}$ and 10 ppm of GBR, respectively, incubated for $48 \mathrm{~h}$ at $37^{\circ} \mathrm{C}$ under near-physiological conditions formed amorphous positively stained deposits showing remnants of a fibrillike morphology. TEM images with $10 \mathrm{kx}$ magnification with scale bar $=200 \mathrm{~nm}$ and $20 \mathrm{kx}$ magnification with scale bar $=100 \mathrm{~nm}$.

extract, $A \beta(1-42)$ appeared negatively stained and showed characteristic fibrillary amyloid morphology. However, in the presence of GBR ( 1 and $10 \mathrm{ppm}), \mathrm{A} \beta(1-42)$ showed amorphous positively stained deposits, resembling remnants of amyloid fibril morphology [34]. In fact, at $10 \mathrm{ppm}$ of GBR, $A \beta(1-42)$ formed distinctly amorphous deposits that appeared very different from those present when GBR was not added. This is consistent with findings on the ability of natural product compounds to inhibit $\mathrm{A} \beta$ aggregation [15].

\subsection{GBR Attenuated Aß(1-42)-Induced Cell Death. GBR} extract ameliorated the aggregation of $\mathrm{A} \beta(1-42)$; thus we further assessed its protective effects on $\mathrm{A} \beta(1-42)$ toxicity in $\mathrm{SH}-\mathrm{SY} 5 Y$ cells. In this study, we incubated aggregated $\mathrm{A} \beta(1-$ 42) with or without the presence of $1 \mathrm{ppm}$ and $10 \mathrm{ppm}$ of GBR extract. Figure 2 shows that incubation of SH-SY5Y cells with $20 \mu \mathrm{M}$ of $\mathrm{A} \beta(1-42)$ decreased the cell viability to $55.5 \%$ as compared to untreated control. Pretreatment of the cells with GBR extract at $1 \mathrm{ppm}$ and $10 \mathrm{ppm}$ was found to substantially increase the cell survival to $59.82 \%$ and $77.02 \%$, respectively. There have been numerous reports on natural compounds with neuroprotective effects against $\mathrm{A} \beta$-induced cell death, many of which exhibited antioxidant properties

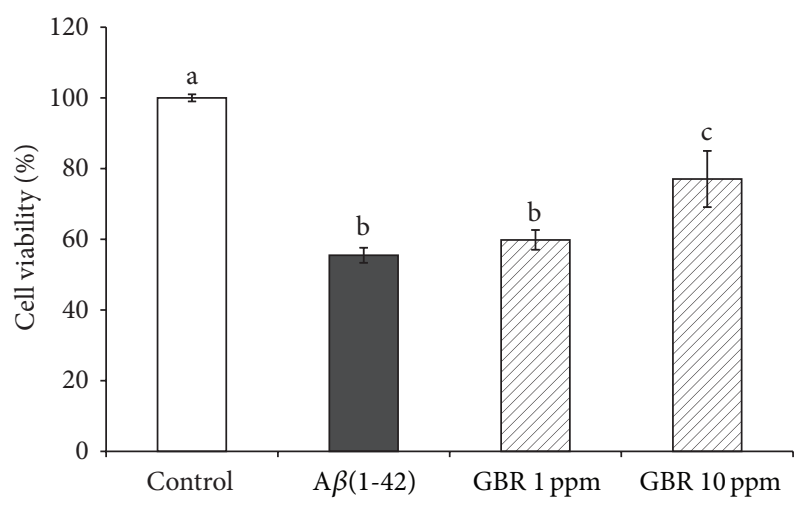

FIGURE 2: MTT analysis on SH-SY5Y cells. Cells were pretreated with GBR extracts at $1 \mathrm{ppm}$ and $10 \mathrm{ppm}$ individually for $24 \mathrm{~h}$ and subsequently incubated with or without $A \beta(1-42)$ for $24 \mathrm{~h}$. Results are expressed as mean \pm SD, different letters representing different groups indicating significant difference $(p<0.05)$.

[30-32]. These antioxidative properties are linked with the regulation of caspase cascade as well as mitogen activated protein kinases (MAPKs) [35, 36]. Moreover, GBR extract 


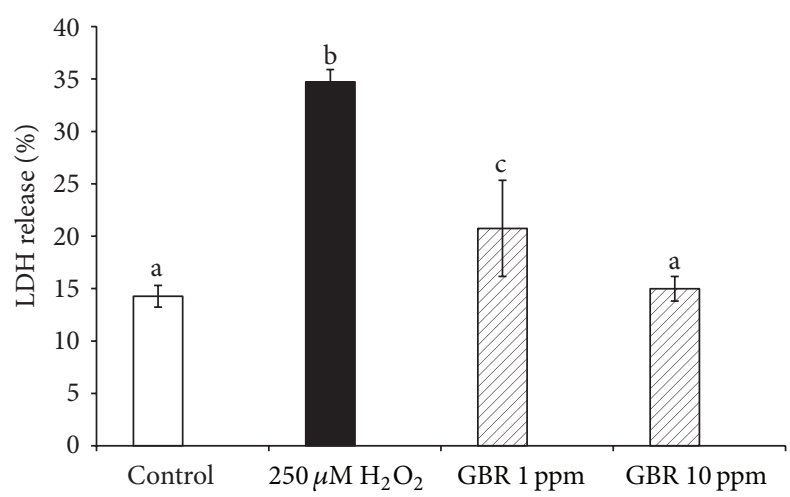

FIgURE 3: Lactate dehydrogenase release from SH-SY5Y cells. Cells were pretreated with GBR extracts at $1 \mathrm{ppm}$ and $10 \mathrm{ppm}$ individually for $24 \mathrm{~h}$ and subsequently incubated with or without $250 \mu \mathrm{M} \mathrm{H}_{2} \mathrm{O}_{2}$ for $2 \mathrm{~h}$. Results are expressed as mean $\pm \mathrm{SD}$, different letters representing different groups indicating significant difference $(p<$ $0.05)$.

used in this study has been previously reported to regulate cell survival and apoptosis pathway through the modulation of MAPKs (JNK, ERK, and p38), p53, AKT, and NF- $\kappa \beta$ [23].

3.4. GBR Attenuated $\mathrm{H}_{2} \mathrm{O}_{2}$-Induced Neurotoxicity. To study the neuroprotective effects of GBR on oxidative stressinduced toxicity in SH-SY5Y cells, the cells were pretreated with GBR at 1 and $10 \mathrm{ppm}$ for $24 \mathrm{~h}$ prior to $\mathrm{H}_{2} \mathrm{O}_{2}$ insult. Figure 3 shows that GBR reduced the release of $\mathrm{LDH}$ from the cells, which may have indicated the amelioration of oxidative stress-induced neurotoxicity in differentiated $\mathrm{SH}$ SY5Y neuroblastoma cells in comparison to nontreated cells. $\mathrm{LDH}$ is a stable cytoplasmic enzyme which is released from the cells due to loss of plasma membrane integrity. In an in vitro model of cell apoptosis, an increase in $\mathrm{LDH}$ activity in the culture supernatant signifies an increase in dead cells or disintegration of plasma membrane. Thus, the measurement of cytosolic LDH release from the cells is commonly used to indicate the loss of membrane integrity especially in apoptotic cells [37].

From the determination of ROS production using DCFHDA as represented by Figure 4, it was observed that $\mathrm{H}_{2} \mathrm{O}_{2}$ increased the level of intracellular ROS throughout the incubation time in comparison to the untreated normal control cells. Cells pretreated with GBR prior to the addition of $\mathrm{H}_{2} \mathrm{O}_{2}$, nevertheless, exhibited lower levels of ROS, in corroboration of the GBR-induced attenuation of neurotoxicity as evidenced by reduced $\mathrm{LDH}$ release. This is in agreement with our previous findings by which an ethyl acetate extract of GBR possessed high antioxidative capacity and regulated several antioxidant genes such as superoxide dismutases (SODs) and catalase [23]. Oxidative stress results from imbalance between the levels of antioxidants and prooxidants and has been the target in the management of many chronic diseases. In the brain, increased levels of oxidative damage are implicated in aging as well as the processes leading up to neurodegenerative diseases like $\mathrm{AD}$. The attenuation of ROS by GBR extract

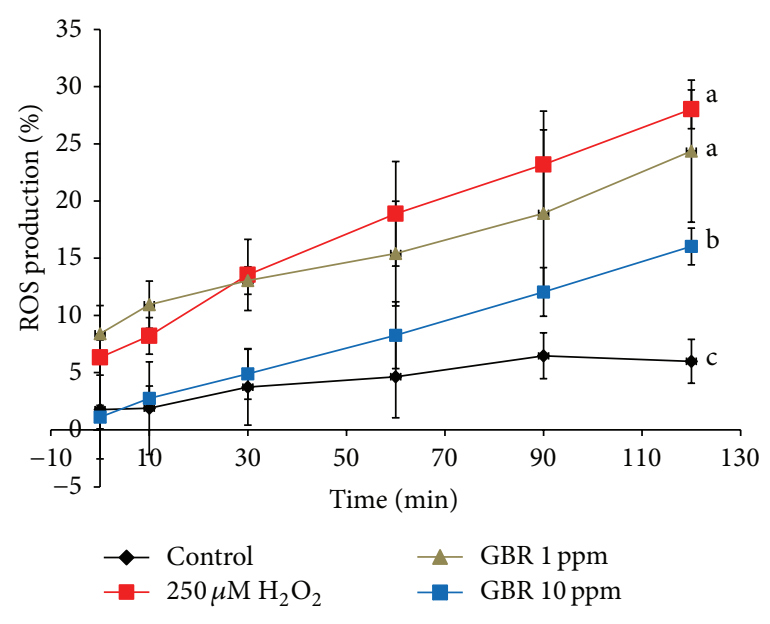

FIGURE 4: Intracellular reactive oxygen species (ROS) generation in SH-SY5Y cells. Cells were pretreated with GBR extracts at $1 \mathrm{ppm}$ and $10 \mathrm{ppm}$ individually for $24 \mathrm{~h}$ and subsequently incubated with or without $250 \mu \mathrm{M} \mathrm{H}_{2} \mathrm{O}_{2}$ for $2 \mathrm{~h}$. Results are expressed as mean $\pm \mathrm{SD}$, different letters representing different groups indicating significant difference $(p<0.05)$.

suggests its potential for attenuating oxidative stress-induced neurotoxicity.

3.5. Transcriptional Regulation of AD-Related Genes by GBR. Oxidative stress plays vital roles in the development of $A \beta$ peptides through the regulation of APP metabolism $[10,14]$. The amyloid-cascade theory hypothesizes that proteolytic cleavage of APP may result in neurotoxic $\beta$-amyloid peptides, which are the hallmark of AD [2]. However, as can be recalled, depending on the site of cleavage of the APP molecule by $\alpha$-, $\beta$-, or $\gamma$-secretases, the metabolic processing of APP may be in favor of amyloidogenic or nonamyloidogenic pathways [3]. Unlike in the nonamyloidogenic pathway which precludes the formation of neurotoxic $\mathrm{A} \beta$, the amyloidogenic pathway produces aggregated, fibrillary complexes termed senile plaques, which were found to be abundant in $\mathrm{AD}$ [38].

In the present study, we analyzed the effects of $\mathrm{H}_{2} \mathrm{O}_{2}$ on $\mathrm{AD}$-related genes as well as the ability of GBR to modulate their transcription (Figure 5). Expression levels of Presenilin 1, Presenilin 2, A $\beta$ cleaving enzymes (BACE1, BACE2), ADAM10, LRP, Neprilysin, and APP were determined. Presenilin 1, Presenilin 2, BACE1, and BACE2 were found to be upregulated as a result of $\mathrm{H}_{2} \mathrm{O}_{2}$-induced oxidative stress in comparison with the untreated normal cells. Furthermore, pretreatment with GBR attenuated the $\mathrm{H}_{2} \mathrm{O}_{2}$-induced transcriptional changes on Presenilin 1, BACE1, and BACE2, but not that of Presenilin 2. Presenilin 1 and Presenilin 2 are important $\gamma$-secretase enzymes with protease activities that cleave APP to produce A $\beta$ fragments, and their deficiency or inhibition may reduce $\mathrm{A} \beta$ production [39]. This has been suggested as a potential target for antiamyloidogenic approach in AD research [40]. On the other hand, BACE1 and its homolog BACE2 form part of the $\beta$-secretases that are involved in the processing of APP to produce $\mathrm{A} \beta$ [41]. 

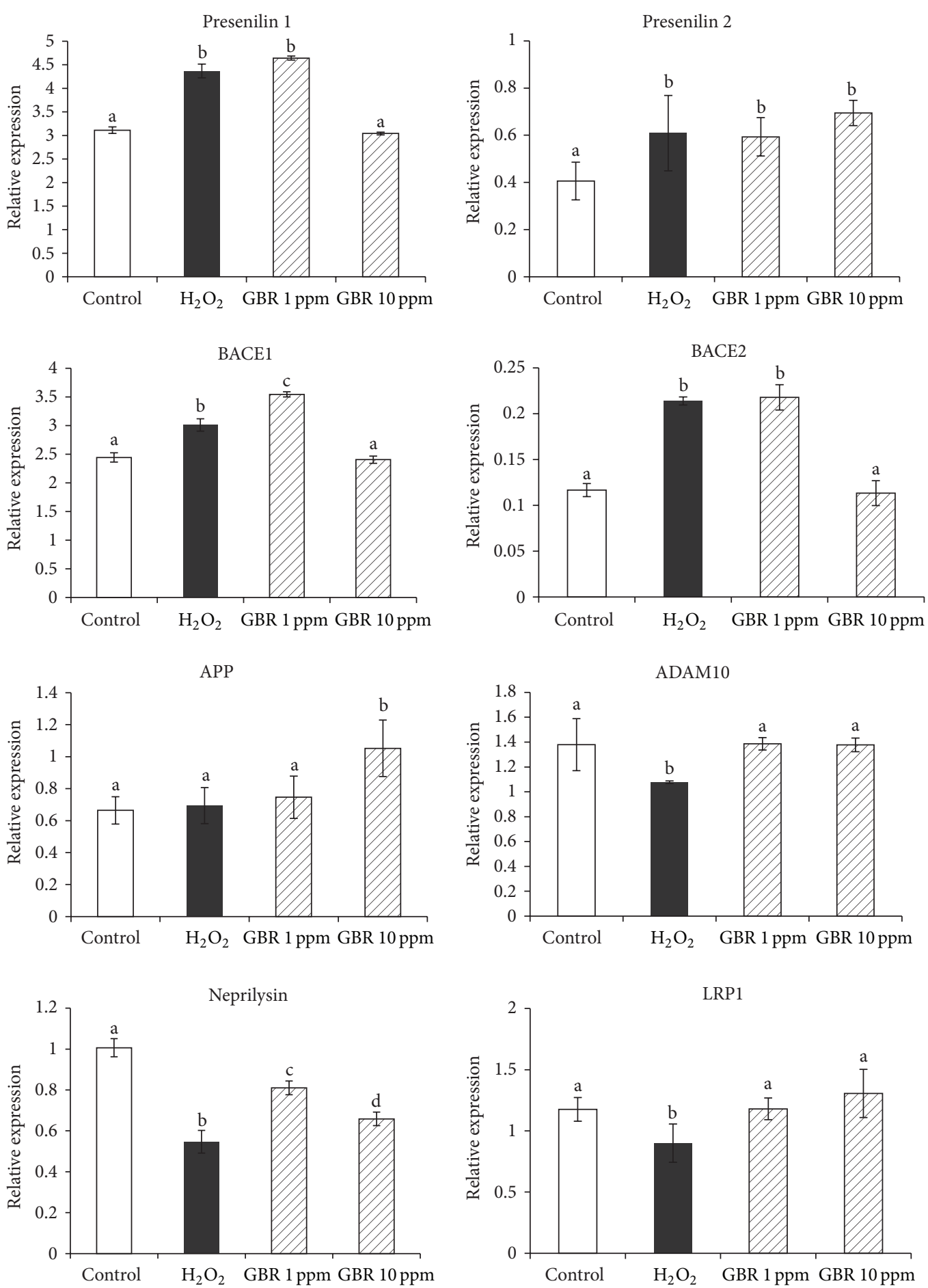

FIGURE 5: mRNA levels of Alzheimer's disease-related genes in differentiated SH-SY5Y neuroblastoma cells induced with $250 \mu \mathrm{M}$ hydrogen peroxide $\left(\mathrm{H}_{2} \mathrm{O}_{2}\right)$, with or without pretreatment with germinated brown rice (GBR) at $1 \mathrm{ppm}$ and $10 \mathrm{ppm}$, respectively. Different letters on bars representing different groups indicating significant difference $(p<0.05)$. ADAM10: a disintegrin and metalloproteinase domain-containing protein 10; APP: amyloid precursor protein; BACE: beta-site APP-cleaving enzyme; LRP: low density lipoprotein receptor-related protein.

BACE2 was reported to be responsible for the release of $\mathrm{A} \beta$ in mutant transfected cells [42] and was able to cleave APP at the secretase cleavage site, in an in vitro model [43]. BACE1, on the other hand, has been established as a more dominant inducer of APP cleavage leading to $\mathrm{A} \beta$ formation $[42,44]$.
Moreover, in a transgenic mice model bearing APP mutation, overexpression of BACE increased the processing of APP and contributed to high levels of $\mathrm{A} \beta$ [45]. This is consistent with findings of elevated BACE activity in the brains of $\mathrm{AD}$ patients with high load of $\mathrm{A} \beta$ plaques [46]. 


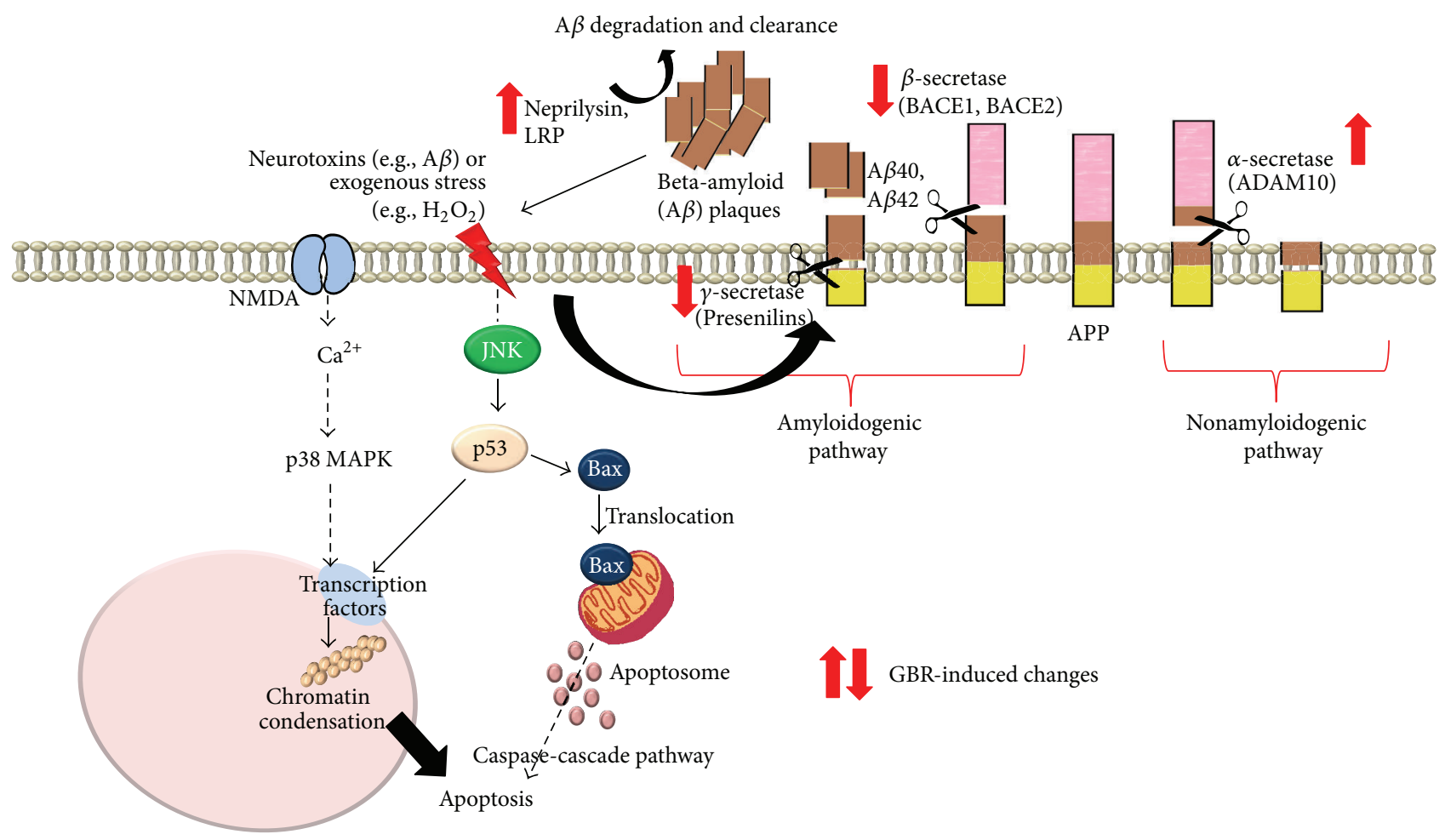

FIgURE 6: Proposed schematic diagram showing targets of germinated brown rice (GBR) in APP processing metabolism pathway. ADAM10: a disintegrin and metalloproteinase domain-containing protein 10; APP: amyloid precursor protein; BACE: beta-site APP-cleaving enzyme; Bax: BCL2-associated X protein; $\mathrm{H}_{2} \mathrm{O}_{2}$ : hydrogen peroxide; JNK: c-Jun N-terminal kinases; LRP: low density lipoprotein receptor-related protein; p53: p53 tumor suppressor.

Although accumulated $\mathrm{A} \beta$ can be toxic, the sAPP $\alpha$ is protective towards neuronal cells. In the present study, $\mathrm{H}_{2} \mathrm{O}_{2}-$ induced oxidative stress did not promote APP expression in comparison to the normal control $(p>0.05)$. Interestingly, we found that pretreatment with GBR (10 ppm) upregulated APP expression. There are reports of the neuroprotective effects of soluble APP mediated by $\alpha$-secretase activity in PC12 cells [47]. Our study also showed that the expression of ADAM10, a part of $\alpha$-secretase, was downregulated under oxidative stress condition, while GBR increased its expression similar to what was observed in the normal control. This is in agreement with previous findings that support the neuroprotective effects of ADAM10 [48], thus suggesting the potential role of $\alpha$-secretases, particularly ADAM10 in the therapeutic development of AD.

Similarly, $\mathrm{H}_{2} \mathrm{O}_{2}$ treatment resulted in reduced expression of Neprilysin and LRP genes when compared to the control $(p<0.05)$. Treating the cells with GBR prior to the $\mathrm{H}_{2} \mathrm{O}_{2}$ insult, nevertheless, resulted in an increased expression of Neprilysin and LRP genes. Moreover, the expression of LRP in GBR-treated cells was found to be dose-dependent, implying that GBR is able to increase the transport of $A \beta$ from the brain into the bloodstream. Aside from its involvement in cholesterol metabolism and transport, LRP binds several ligands including ApoE, APP, and A $\beta$ [49] and has been demonstrated to regulate the clearance of $A \beta$ from the brain into the bloodstream [50]. Accordingly, $A \beta$ transport clearance across the blood-brain barrier (BBB) in mice was reported to decrease with aging [51], the basis of which may be the loss of LRP transport and hence the accumulation of $\mathrm{A} \beta$ in blood vessels and perivascular brain tissue, as demonstrated in aged individuals [52]. Similarly, brain vascular dysfunction, reduced cerebral blood flow, BBB leakage, and accumulation of multiple blood-derived vasculotoxins and neurotoxins following injury to brain endothelial cells have recently been shown to collectively contribute to $\mathrm{AD}$ pathogenesis [53]. Moreover, $A \beta$ binds to brain endothelial LRP1 at the abluminal side of the BBB and clears into the peripheral circulation [54] and has been demonstrated to induce oxidative stress and mediates $\mathrm{BBB}$ changes and brain capillary dysfunction [55]. Conversely, antioxidants in GBR extract may protect brain vasculature and improve LRP1 mediated clearance of $\mathrm{A} \beta$, thereby attenuating the effects of $A \beta$-induced toxicity. On the other hand, Neprilysin is reported to contribute towards the degradation of $A \beta$ [56]. In the hippocampal region of $\mathrm{AD}$ patients, it was demonstrated that Neprilysin mRNA and protein levels were significantly lower than in control subjects [57]. Accordingly, deficiency in Neprilysin may result in limited degradation of both endogenously produced $A \beta$ and exogenously administered $\mathrm{A} \beta$ [58] and could eventually promote the accumulation of $\mathrm{A} \beta$ in AD. Thus, regulation of LRP and Neprilysin genes by GBR suggested that the neuroprotective effects of GBR in reducing the accumulation of $A \beta$ are partly mediated by increased degradation and clearance of $A \beta$ from the brain tissue. 
Based on the transcriptional regulation of $\mathrm{AD}$-related genes by GBR, in neuronal cells that have been exposed to $\mathrm{H}_{2} \mathrm{O}_{2}$, we propose that the mechanistic basis for the neuroprotective effects of GBR may be through multiple pathways (Figure 6) including the regulation of APP metabolism genes as well as apoptosis pathway involving JNK, ERK, and p53, as we have previously demonstrated [23]. The antiamyloidogenic effects of GBR may be due to its bioactive-rich content with potent antioxidant effects that are able to counter $\mathrm{H}_{2} \mathrm{O}_{2}$ induced neurotoxicity.

\section{Conclusion}

In the present study, we demonstrated that GBR modified the structure of $\mathrm{A} \beta(1-42)$ when incubated together and also protected neuronal cells from $\mathrm{H}_{2} \mathrm{O}_{2}$-induced neurotoxicity (reduced $\mathrm{LDH}$ release) partly through reduced oxidative stress (lowered ROS production). We also showed that transcriptional regulation of $\mathrm{AD}$-related genes by GBR tended towards neuroprotection. As such, we propose that GBR not only possesses the potential to manage oxidative stress and oxidative stress-induced $\mathrm{A} \beta$ formation, but also can reduce the aggregation of $\mathrm{A} \beta$ as well as increase its clearance and degradation. Further work involving in vivo model to assess the effectiveness of GBR at physiological level is of importance and is therefore indicated.

\section{Abbreviations}

$\begin{array}{ll}\text { AD: } & \text { Alzheimer's disease } \\ \text { A }: & \text { Beta-amyloid } \\ \mathrm{H}_{2} \mathrm{O}_{2}: & \text { Hydrogen peroxide } \\ \text { GBR: } & \text { Germinated brown rice } \\ \text { APP: } & \text { Amyloid precursor protein beta-site } \\ \text { BACE: } & \text { Beta-site APP-cleaving enzyme } \\ \text { ADAM10: } & \text { A disintegrin and metalloproteinase } \\ & \text { domain-containing protein } 10 \\ \text { LRP: } & \text { Low density lipoprotein } \\ & \text { receptor-related protein } \\ \text { ROS: } & \text { Reactive oxygen species } \\ \text { BR: } & \text { Brown rice } \\ \text { PBS: } & \text { Phosphate-buffered saline } \\ \text { NaOCl: } & \text { Sodium hypochlorite } \\ \text { DCFH-DA: } & \text { Dichlorodihydrofluorescein diacetate } \\ \text { DCF: } & \text { 2V,7V-Dichlorofluorescein } \\ \text { TEM: } & \text { Transmission Electron Microscopy } \\ \text { LDH: } & \text { Lactate dehydrogenase } \\ \text { HPLC: } & \text { High performance liquid } \\ & \text { chromatography } \\ \text { SOD: } & \text { Superoxide dismutase } \\ \text { ACTB: } & \text { Beta-actin } \\ \text { GAPDH: } & \text { Glyceraldehyde 3-phosphate } \\ & \text { dehydrogenase } \\ & \end{array}$

\section{Conflict of Interests}

The authors declare that there is no conflict of interests regarding the publication of this paper.

\section{Authors' Contribution}

Nur Hanisah Azmi carried out the experimental parts and drafted the paper. Maznah Ismail, Norsharina Ismail, Noorjahan Banu Mohammed Alitheen, and Maizaton Atmadini Abdullah participated in the design of the study and supervised the work. Mustapha Umar Imam critically revised the paper content. All authors read and approved the final paper.

\section{Acknowledgments}

This study was funded by Padiberas Nasional Berhad (BERNAS) and supported by Universiti Putra Malaysia (UPM). The authors would like to express gratitude to Ms. Norhayati Yusuf from the Laboratory of Molecular Biomedicine and Mr. Rafiuz-Zaman Haroun from the Electron Microscopy Unit, Institute of Bioscience, UPM, for technical assistance during the completion of this work.

\section{References}

[1] D. Selkoe, E. Mandelkow, and D. Holtzman, "Deciphering alzheimer disease," Cold Spring Harbor Perspectives in Medicine, vol. 2, no. 1, Article ID a011460, 2012.

[2] J. A. Hardy and D. J. Selkoe, "The amyloid hypothesis of Alzheimer's disease: progress and problems on the road to therapeutics," Science, vol. 297, no. 5580, pp. 353-356, 2002.

[3] W. P. Esler and M. S. Wolfe, "A portrait of Alzheimer secretases-new features and familiar faces," Science, vol. 293, no. 5534, pp. 1449-1454, 2001.

[4] S. Parvathy, I. Hussain, E. H. Karran, A. J. Turner, and N. M. Hooper, "Cleavage of Alzheimer's amyloid precursor protein by $\alpha$-secretase occurs at the surface of neuronal cells," Biochemistry, vol. 38, no. 30, pp. 9728-9734, 1999.

[5] R. Vassar, B. D. Bennett, S. Babu-Khan et al., " $\beta$-Secretase cleavage of Alzheimer's amyloid precursor protein by the transmembrane aspartic protease BACE," Science, vol. 286, no. 5440, pp. 735-741, 1999.

[6] R. Francis, G. McGrath, J. Zhang et al., "aph-1 and pen-2 are required for Notch pathway signaling, $\gamma$-secretase cleavage of $\beta \mathrm{APP}$, and presenilin protein accumulation," Developmental Cell, vol. 3, no. 1, pp. 85-97, 2002.

[7] W. T. Kimberly, M. J. LaVoie, B. L. Ostaszewski, W. Ye, M. S. Wolfe, and D. J. Selkoe, " $\gamma$-Secretase is a membrane protein complex comprised of presenilin, nicastrin, aph-1, and pen-2," Proceedings of the National Academy of Sciences of the United States of America, vol. 100, no. 11, pp. 6382-6387, 2003.

[8] A. Goate, M.-C. Chartier-Harlin, M. Mullan et al., "Segregation of a missense mutation in the amyloid precursor protein gene with familial Alzheimer's disease," Nature, vol. 349, no. 6311, pp. 704-706, 1991.

[9] D. Scheuner, C. Eckman, M. Jensen et al., "Secreted amyloid $\beta$-protein similar to that in the senile plaques of Alzheimer's disease is increased in vivo by the presenilin 1 and 2 and APP mutations linked to familial Alzheimer's disease," Nature Medicine, vol. 2, no. 8, pp. 864-870, 1996.

[10] R. Quiroz-Baez, E. Rojas, and C. Arias, "Oxidative stress promotes JNK-dependent amyloidogenic processing of normally expressed human APP by differential modification of $\alpha$-, $\beta$ - and $\gamma$-secretase expression," Neurochemistry International, vol. 55, no. 7, pp. 662-670, 2009. 
[11] Y. Tong, W. Zhou, V. Fung et al., "Oxidative stress potentiates BACE1 gene expression and A $\beta$ generation," Journal of Neural Transmission, vol. 112, no. 3, pp. 455-469, 2005.

[12] S. S. Hébert, K. Horré, L. Nicolaï et al., "Loss of microRNA cluster miR-29a/b-1 in sporadic Alzheimer's disease correlates with increased BACE1/ $\beta$-secretase expression," Proceedings of the National Academy of Sciences of the United States of America, vol. 105, no. 17, pp. 6415-6420, 2008.

[13] M. P. Mattson, S. W. Barger, B. Cheng, I. Lieberburg, V. L. Smith-Swintosky, and R. E. Rydel, " $\beta$-Amyloid precursor protein metabolites and loss of neuronal $\mathrm{Ca}^{2+}$ homeostasis in Alzheimer's disease," Trends in Neurosciences, vol. 16, no. 10, pp. 409-414, 1993.

[14] A. Nunomura, G. Perry, G. Aliev et al., "Oxidative damage is the earliest event in Alzheimer disease," Journal of Neuropathology \& Experimental Neurology, vol. 60, no. 8, pp. 759-767, 2001.

[15] V. Di Matteo, M. Pierucci, G. Di Giovanni, and E. Esposito, "Prevention and therapy of neurodegenerative disorders: role of nutritional antioxidants," in Oxidative Stress and Neurodegenerative Disorders, G. A. Qureshi and S. H. Parvez, Eds., pp. 621661, 2007.

[16] M. U. Imam, S. N. A. Musa, N. H. Azmi, and M. Ismail, "Effects of white rice, brown rice and germinated brown rice on antioxidant status of type 2 diabetic rats," International Journal of Molecular Sciences, vol. 13, no. 10, pp. 12952-12969, 2012.

[17] I. M. Sani, S. Iqbal, K. W. Chan, and M. Ismail, "Effect of acid and base catalyzed hydrolysis on the yield of phenolics and antioxidant activity of extracts from germinated brown rice (GBR)," Molecules, vol. 17, no. 6, pp. 7584-7594, 2012.

[18] N. Ismail, M. Ismail, S. F. Fathy et al., "Neuroprotective effects of germinated brown rice against hydrogen peroxide induced cell death in human SH-SY5Y cells," International Journal of Molecular Sciences, vol. 13, no. 8, pp. 9692-9708, 2012.

[19] R. Soi-Ampornkul, S. Kanyok, S. Junnu et al., "Potent antioxidant and anti-apoptotic activity of pre-germinated brown rice extract against hydrogen peroxide in neuronal SK-N-SH cells: a model of Alzheimer's disease," Alzheimer's \& Dementia, vol. 8, no. 4, supplement, p. P503, 2012.

[20] T. Mamiya, M. Kise, K. Morikawa, H. Aoto, M. Ukai, and Y. Noda, "Effects of pre-germinated brown rice on depression-like behavior in mice," Pharmacology Biochemistry and Behavior, vol. 86, no. 1, pp. 62-67, 2007.

[21] T. Mamiya, T. Asanuma, M. Kise et al., "Effects of pregerminated brown rice on $\beta$-amyloid protein-induced learning and memory deficits in mice," Biological and Pharmaceutical Bulletin, vol. 27, no. 7, pp. 1041-1045, 2004.

[22] S. B. Patil and M. K. Khan, "Germinated brown rice as a value added rice product: a review," Journal of Food Science and Technology, vol. 48, no. 6, pp. 661-667, 2011.

[23] N. H. Azmi, N. Ismail, M. U. Imam, and M. Ismail, "Ethyl acetate extract of germinated brown rice attenuates hydrogen peroxideinduced oxidative stress in human SH-SY5Y neuroblastoma cells: role of anti-apoptotic, pro-survival and antioxidant genes," BMC Complementary and Alternative Medicine, vol. 13, no. 1, pp. 177-187, 2013.

[24] A. Azlan, M. Ismail, and A. Abdul Hamid, "Extraction and determination of oryzanol in rice bran of mixed herbarium UKMB; AZ 6807: MR 185, AZ 6808: MR 211, AZ6809: MR 29," ASEAN Food Journal, vol. 15, no. 1, pp. 89-96, 2008.

[25] A. R. Rosenkranz, S. Schmaldienst, K. M. Stuhlmeier, W. Chen, W. Knapp, and G. J. Zlabinger, "A microplate assay for the detection of oxidative products using $2^{\prime}, 7^{\prime}$-dichlorofluorescindiacetate," Journal of Immunological Methods, vol. 156, no. 1, pp. 39-45, 1992.

[26] M. U. Imam, N. H. Azmi, M. I. Bhanger, N. Ismail, and M. Ismail, "Antidiabetic properties of germinated brown rice: a systematic review," Evidence-Based Complementary and Alternative Medicine, vol. 2012, Article ID 816501, 12 pages, 2012.

[27] M. U. Imam, M. Ismail, D. J. Ooi et al., "Are bioactive-rich fractions functionally richer?" Critical Reviews in Biotechnology, 2015.

[28] C. A. Rice-Evans, N. J. Miller, and G. Paganga, "Antioxidant properties of phenolic compounds," Trends in Plant Science, vol. 2, no. 4, pp. 152-159, 1997.

[29] M. T. Heneka, M. P. Kummer, S. Weggen et al., "Molecular mechanisms and therapeutic application of NSAIDs and derived compounds in Alzheimer's disease," Current Alzheimer Research, vol. 8, no. 2, pp. 115-131, 2011.

[30] S.-G. Yang, W.-Y. Wang, T.-J. Ling et al., "Alpha-tocopherol quinone inhibits beta-amyloid aggregation and cytotoxicity, disaggregates preformed fibrils and decreases the production of reactive oxygen species, NO and inflammatory cytokines," Neurochemistry International, vol. 57, no. 8, pp. 914-922, 2010.

[31] B. S. Harvey, I. F. Musgrave, K. S. Ohlsson, A. Fransson, and S. D. Smid, "The green tea polyphenol (-)-epigallocatechin-3gallate inhibits amyloid- $\beta$ evoked fibril formation and neuronal cell death in vitro," Food Chemistry, vol. 129, no. 4, pp. 1729-1736, 2011.

[32] E. Janefjord, J. L. V. Mååg, B. S. Harvey, and S. D. Smid, "Cannabinoid effects on $\beta$ amyloid fibril and aggregate formation, neuronal and microglial-activated neurotoxicity in vitro," Cellular and Molecular Neurobiology, vol. 34, no. 1, pp. 31-42, 2014.

[33] R. Pi, X. Mao, X. Chao et al., "Tacrine-6-ferulic acid, a novel multifunctional dimer, inhibits amyloid- $\beta$-mediated Alzheimer's disease-associated pathogenesis in vitro and in vivo," PLoS ONE, vol. 7, no. 2, Article ID e31921, 2012.

[34] M. Mold, L. Ouro-Gnao, B. M. Wieckowski, and C. Exley, "Copper prevents amyloid- $\beta_{1-42}$ from forming amyloid fibrils under near-physiological conditions in vitro," Scientific Reports, vol. 3, article 1256, 2013.

[35] X. Tian, S. Sui, J. Huang, J.-P. Bai, T.-S. Ren, and Q.-C. Zhao, "Neuroprotective effects of Arctium lappa L. roots against glutamate-induced oxidative stress by inhibiting phosphorylation of p38, JNK and ERK 1/2 MAPKs in PC12 cells," Environmental Toxicology and Pharmacology, vol. 38, no. 1, pp. 189-198, 2014.

[36] Q. He, L. Bao, J. Zimering et al., "The protective role of (-)epigallocatechin-3-gallate in thrombin-induced neuronal cell apoptosis and JNK-MAPK activation," NeuroReport, vol. 26, no. 7, pp. 416-423, 2015.

[37] H. O. Jauregui, N. T. Hayner, J. L. Driscoll, R. Williams-Holland, M. H. Lipsky, and P. M. Galletti, "Trypan blue dye uptake and lactate dehydrogenase in adult rat hepatocytes-freshly isolated cells, cell suspensions, and primary monolayer cultures," In Vitro, vol. 17, no. 12, pp. 1100-1110, 1981.

[38] F. M. LaFerla, K. N. Green, and S. Oddo, "Intracellular amyloid$\beta$ in Alzheimer's disease," Nature Reviews Neuroscience, vol. 8, no. 7, pp. 499-509, 2007.

[39] I. Dewachter, D. Reversé, N. Caluwaerts et al., "Neuronal deficiency of presenilin 1 inhibits amyloid plaque formation and corrects hippocampal long-term potentiation but not a cognitive defect of amyloid precursor protein [V717I] transgenic 
mice," The Journal of Neuroscience, vol. 22, no. 9, pp. 3445-3453, 2002.

[40] B. De Strooper, R. Vassar, and T. Golde, "The secretases: enzymes with therapeutic potential in Alzheimer disease," Nature Reviews Neurology, vol. 6, no. 2, pp. 99-107, 2010.

[41] H. Cai, Y. Wang, D. McCarthy et al., "BACE1 is the major $\beta$ secretase for generation of $\mathrm{A} \beta$ peptides by neurons," Nature Neuroscience, vol. 4, no. 3, pp. 233-234, 2001.

[42] I. Hussain, D. J. Powell, D. R. Howlett et al., "Asp1 (BACE2) cleaves the amyloid precursor protein at the $\beta$-secretase site," Molecular and Cellular Neuroscience, vol. 16, no. 5, pp. 609-619, 2000.

[43] M. Farzan, C. E. Schnitzler, N. Vasilieva, D. Leung, and H. Choe, "BACE2, a $\beta$-secretase homolog, cleaves at the $\beta$ site and within the amyloid- $\beta$ region of the amyloid- $\beta$ precursor protein," Proceedings of the National Academy of Sciences of the United States of America, vol. 97, no. 17, pp. 9712-9717, 2000.

[44] B. D. Bennett, S. Babu-Khan, R. Loeloff et al., "Expression analysis of BACE2 in brain and peripheral tissues," Journal of Biological Chemistry, vol. 275, no. 27, pp. 20647-20651, 2000.

[45] U. Bodendorf, S. Danner, F. Fischer et al., "Expression of human $\beta$-secretase in the mouse brain increases the steady-state level of $\beta$-amyloid," Journal of Neurochemistry, vol. 80, no. 5, pp. 799806, 2002.

[46] R. Li, K. Lindholm, L.-B. Yang et al., "Amyloid $\beta$ peptide load is correlated with increased $\beta$-secretase activity in sporadic Alzheimer's disease patients," Proceedings of the National Academy of Sciences of the United States of America, vol. 101, no. 10, pp. 3632-3637, 2004.

[47] Y. Levites, T. Amit, S. Mandel, and M. B. Youdim, "Neuroprotection and neurorescue against $\mathrm{A} \beta$ toxicity and PKC-dependent release of nonamyloidogenic soluble precursor protein by green tea polyphenol (-)-epigallocatechin-3-gallate," The FASEB Journal, vol. 17, no. 8, pp. 952-954, 2003.

[48] R. Postina, A. Schroeder, I. Dewachter et al., "A disintegrinmetalloproteinase prevents amyloid plaque formation and hippocampal defects in an Alzheimer disease mouse model," Journal of Clinical Investigation, vol. 113, no. 10, pp. 1456-1464, 2004.

[49] J. Herz and D. K. Strickland, "LRP: a multifunctional scavenger and signaling receptor," The Journal of Clinical Investigation, vol. 108, no. 6, pp. 779-784, 2001.

[50] M. Shibata, S. Yamada, S. Ram Kumar et al., "Clearance of Alzheimer's amyloid- $\beta 1-40$ peptide from brain by LDL receptor-related protein-1 at the blood-brain barrier," Journal of Clinical Investigation, vol. 106, no. 12, pp. 1489-1499, 2000.

[51] R. Deane, A. Sagare, K. Hamm et al., "IgG-assisted agedependent clearance of Alzheimer's amyloid $\beta$ peptide by the blood-brain barrier neonatal Fc receptor," The Journal of Neuroscience, vol. 25, no. 50, pp. 11495-11503, 2005.

[52] B. V. Zlokovic, “Cerebrovascular transport of Alzheimer's amyloid $\beta$ and apolipoproteins J and E: possible anti-amyloidogenic role of the blood-brain barrier," Life Sciences, vol. 59, no. 18, pp. 1483-1497, 1996.

[53] B. V. Zlokovic, "New therapeutic targets in the neurovascular pathway in Alzheimer's disease," Neurotherapeutics, vol. 5, no. 3, pp. 409-414, 2008.

[54] B. V. Zlokovic, R. Deane, A. P. Sagare, R. D. Bell, and E. A. Winkler, "Low-density lipoprotein receptor-related protein1: a serial clearance homeostatic mechanism controlling Alzheimer's amyloid $\beta$-peptide elimination from the brain," Journal of Neurochemistry, vol. 115, no. 5, pp. 1077-1089, 2010.
[55] A. Carrano, J. J. M. Hoozemans, S. M. van der Vies, A. J. M. Rozemuller, J. van Horssen, and H. E. de Vries, "Amyloid beta induces oxidative stress-mediated blood-brain barrier changes in capillary amyloid angiopathy," Antioxidants and Redox Signaling, vol. 15, no. 5, pp. 1167-1178, 2011.

[56] N. Iwata, S. Tsubuki, Y. Takaki et al., "Identification of the major A $\beta 1$-42-degrading catabolic pathway in brain parenchyma: suppression leads to biochemical and pathological deposition," Nature Medicine, vol. 6, no. 2, pp. 143-150, 2000.

[57] K. Yasojima, H. Akiyama, E. G. McGeer, and P. L. McGeer, "Reduced neprilysin in high plaque areas of Alzheimer brain: a possible relationship to deficient degradation of $\beta$-amyloid peptide," Neuroscience Letters, vol. 297, no. 2, pp. 97-100, 2001.

[58] N. Iwata, S. Tsubuki, Y. Takaki et al., "Metabolic regulation of brain A $\beta$ by neprilysin," Science, vol. 292, no. 5521, pp. 1550 $1552,2001$. 


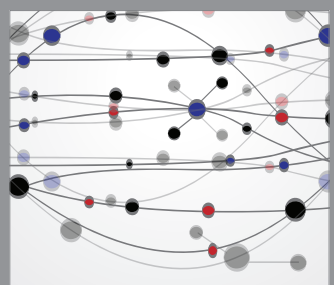

The Scientific World Journal
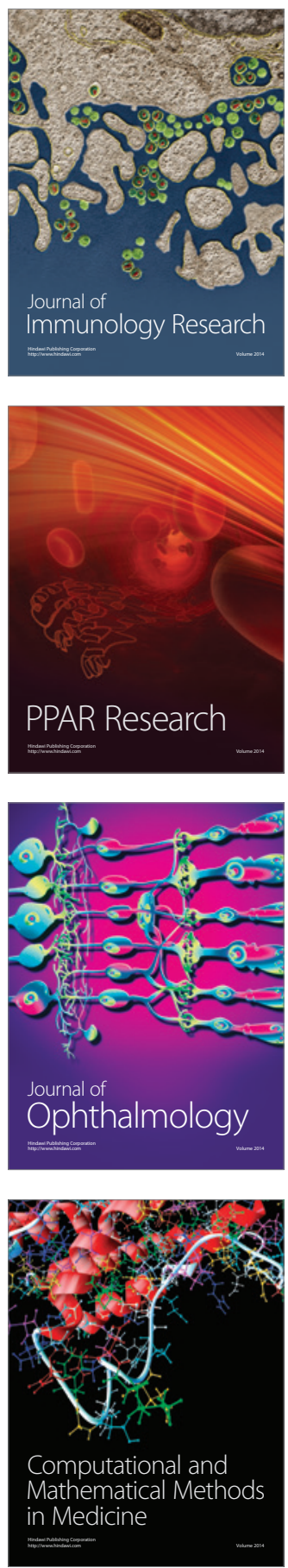

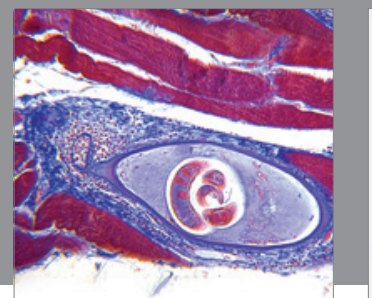

Gastroenterology

Research and Practice
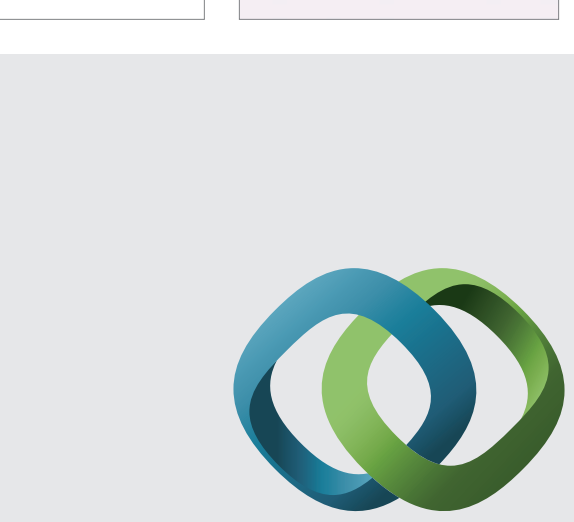

\section{Hindawi}

Submit your manuscripts at

http://www.hindawi.com
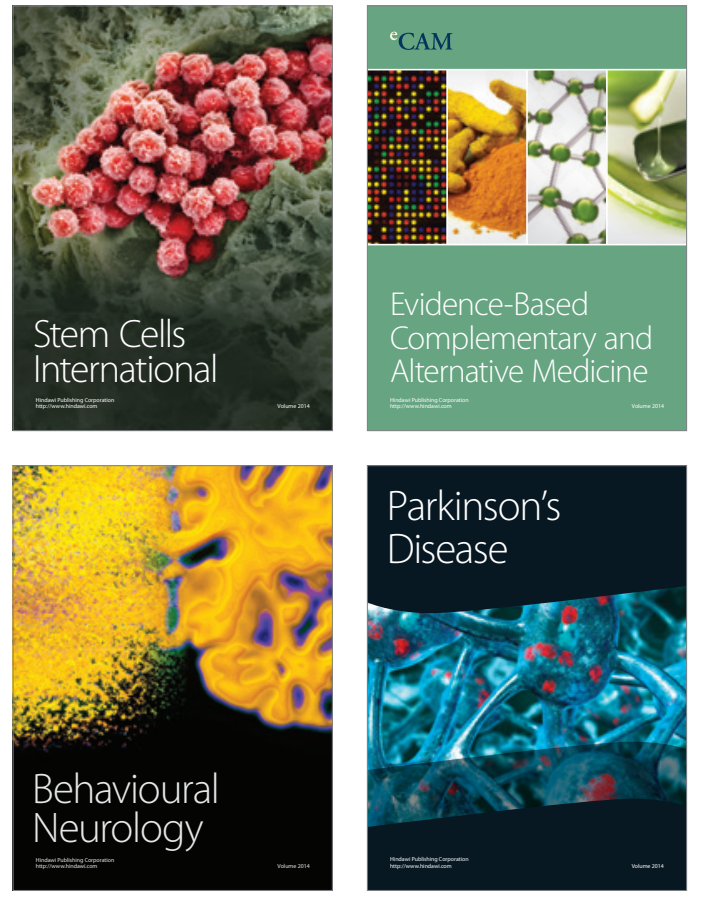
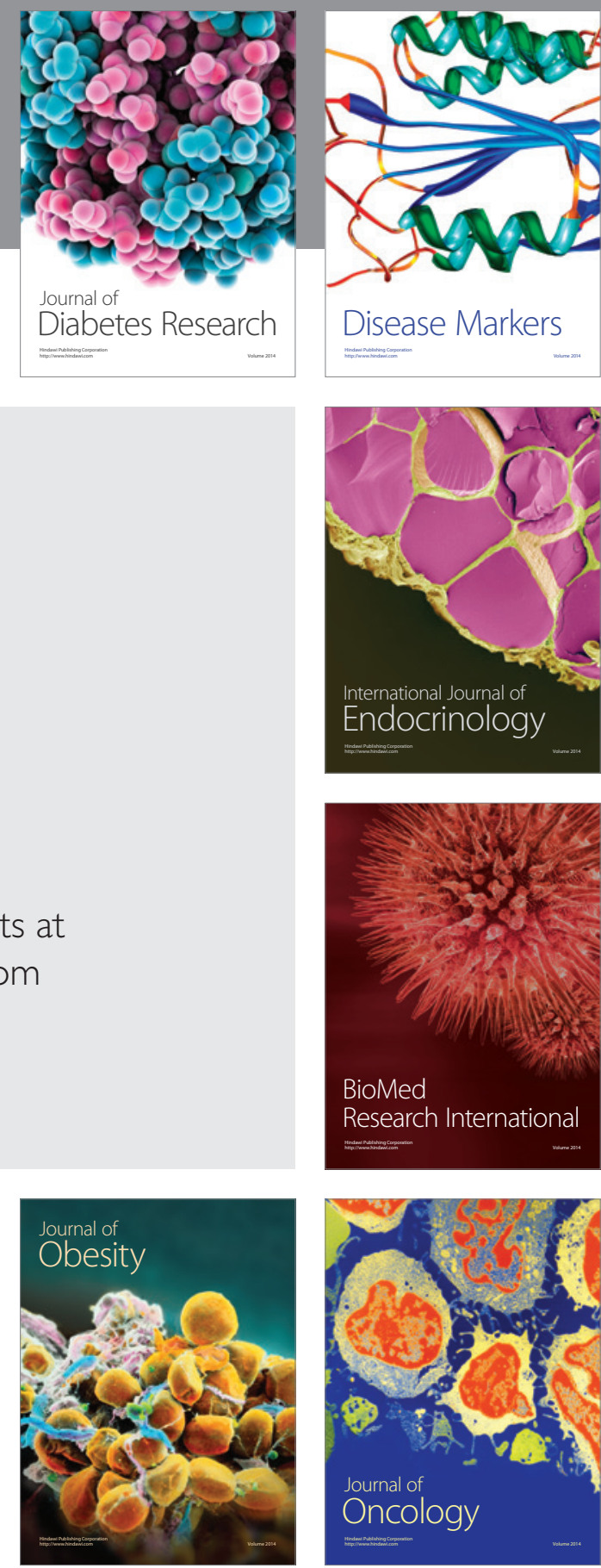

Disease Markers
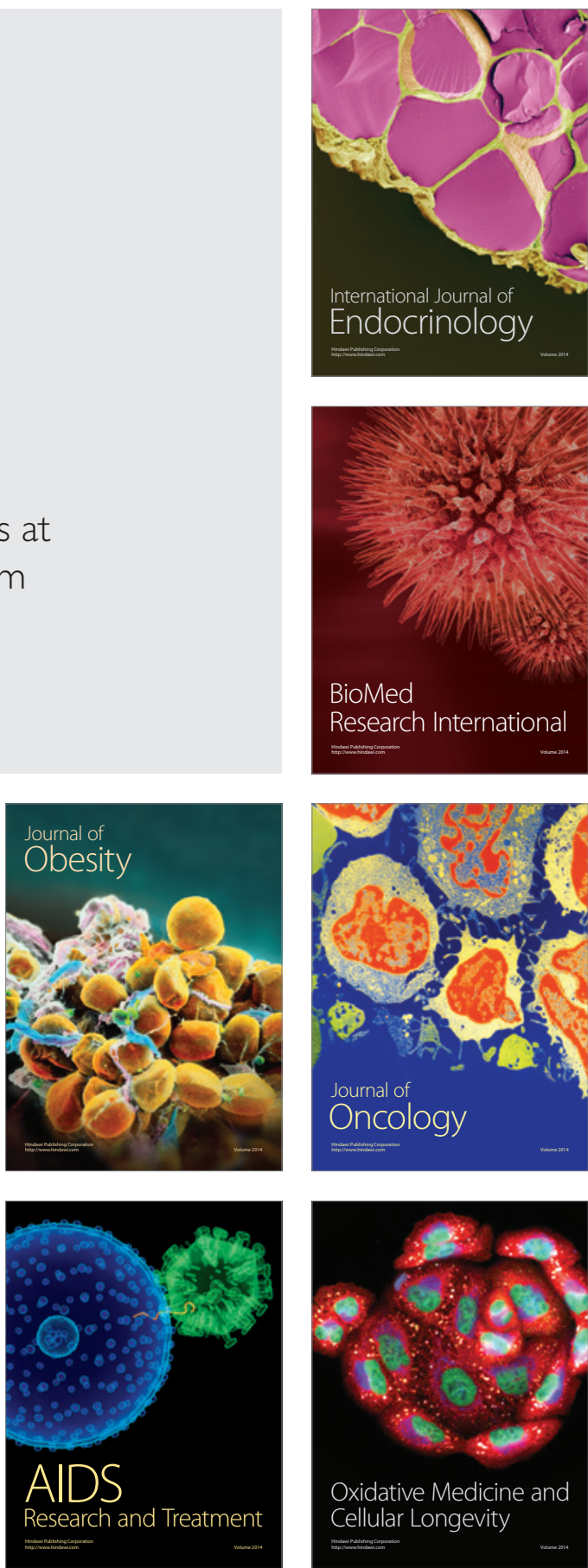